\title{
Preferential Suppression of Insulin-Stimulated Proliferation of Cultured Hepatocytes by Somatostatin: Evidence For Receptor-Mediated Growth Regulation
}

\author{
Piyush C. Kothary, Norihiro Kokudo, F.E. Eckhauser, John DelValle, and Steven E. Raper \\ Departments of Ophthalmology (P.C.K.); Surgery (F.E.E.), and Medicine (J.D.), University of Michigan \\ Medical Center, Ann Arbor, Michigan 48109-0714; Howard Hughes Institute, University of Pennsylvania, \\ Philadelphia, Pennsylvania (S.E.R.); Department of Surgery, University of Tokyo, Tokyo, Japan (N.K.)
}

\begin{abstract}
The role of somatostatin (SS-14) in the regulation of rat liver regeneration was examined by using thymidine incorporation into hepatocyte DNA labeled with tritiated thymidine, a nuclear-labeling index, and the binding of ${ }^{125} \mathrm{I}$-tyr ${ }^{11}$-SS-14 to hepatocytes isolated at various times after partial hepatectomy. The data demonstrated no suppressive effect of SS-14 on insulin and glucagon-stimulated thymidine incorporation into hepatocyte DNA as early as $2 \mathrm{~h}$ after partial hepatectomy. These data were substantiated by a nuclear labeling index studies. At 2 h, ${ }^{125}$ I-tyr ${ }^{11}$-SS-14 binding to its specific sites on isolated hepatocytes was undetectable. There was a time-dependent increase in binding of ${ }^{125}$-tyr ${ }^{11}$-SS-14 to hepatocytes obtained at various times after partial hepatectomy. There was a significant decrease in the number of binding sites after partial hepatectomy as determined by Scatchard analysis. The data were supported by autoradiography analysis of affinity labeled ${ }^{125} \mathrm{I}$-ty $\mathrm{r}^{11}$-SS-14-binding protein complex followed by SDS-PAGE. SS-14 also inhibited intracellular CAMP in hepatocytes obtained at $18 \mathrm{~h}$ after hepatectomy. The data are consistent with the hypothesis that SS-14 participates via its own receptor in the regulation of the liver regeneration. 1995 Wiley-Liss, Inc.
\end{abstract}

Key words: liver regeneration, somatostatin, receptor, cell growth

Somatostatin (SS-14), a 14 amino acid peptide, was first isolated from the hypothalamus as an inhibitor of growth hormone secretion [Brazeau et al., 1973] and has been shown to have paracrine, autocrine, and endocrine action on brain and gastrointestinal functions [Brazeau et al., 1973; Larsson et al., 1979]. Somatostatin and its analogues are potent inhibitors of several tumors and pancreas and cultured hepatocyte proliferation [Harris, 1990; Morriset, 1984; Kokudo et al., 1991]. Nanomolar concentrations of SS-14 inhibit DNA synthesis stimulated by insulin and other growth factors in normal cultured male rat hepatocytes, but selectively inhibit it in human hepatoma cells [Chou et al., 1987]. Further, the inhibitory effect of insulin and IBMX-stimulated hepatocytes proliferation appears to be mediated by the adenylate cyclase system [Raper et al., 1991b].

Received November 21, 1994; accepted March 10, 1995.

Address reprint requests to Piyush C. Kothary, 517 Kellogg Eye Center, University of Michigan Medical Center, Ann Arbor, MI 48109-0714.
In addition to the potent inhibitory effect of SS-14 on hepatocyte proliferation in culture, the liver has been shown to be a major site of SS-14 metabolism [Conlon et al., 1981; Ruggere and Patel, 1985; Raper et al., 1991a]. After an intrahepatic injection ${ }^{125}{ }^{2}$-tyr ${ }^{11}$-SS-14, we [Raper et al., 1991a] found the highest amount of injected ${ }^{125}$ I-tyr ${ }^{11}$-SS-14 in the liver and bile. The hepatic uptake of ${ }^{125}$ I-tyr-SS-14 decreases significantly when synthetic SS-14 is injected, suggesting specific receptor mediated action. Specific and saturable binding sites of molecular weight of 70,000 daltons have been demonstrated on rat liver plasma membranes [Raper et al., 1992].

To test the hypothesis that SS-14 can regulate the early phase of hepatocyte proliferation, we studied its effect at different time intervals on the EGF stimulated tritiated thymidine incorporation into isolated rat hepatocyte DNA. Exposure of hepatocytes to SS-14 between 0 and $24 \mathrm{~h}$ significantly inhibited EGF stimulated hepatocytes proliferation but had no effect when SS-14 was added between 48-72 h [Kokudo et al., 1992]. 
In the present study, we examined the effects of SS-14 on insulin stimulated isolated normal and regenerating liver hepatocytes proliferation and cAMP levels. We also identified and characterized SS-14 binding sites on these hepatocytes. We conclude that SS-14 may function as a regulator of a negative control for the hepatocytes proliferation via its receptor.

\section{MATERIALS AND METHODS Chemicals}

Protease inhibitors and agarose were bought from Sigma Chemical Co. (St. Louis, MO). Peptides were obtained from Peninsula Laboratory (Belmont, CA). Radioactive chemicals were obtained from Amersham (Arlington, IL). Reagents for gel electrophoresis and protein estimations were obtained from Bio-Rad Laboratories (Richmond, VA). Disuccimidyl suberate (DSS) was obtained from Boeringer-Mannheim (Indianapolis, IN). Reagents for autoradiography were obtained from Eastman Kodak Co. (Rochester, NY).

\section{Partial Hepatectomy and Hepatocyte Isolation}

Partial hepatectomy (70\% HTX) was performed on an anesthetized Sprague-Dawley male rat (250-275 g) after midline laparotomy by aseptic extirpation of the median and left lateral lobes [Hashimoto et al., 1993]. The mortality rate was less than $2 \%$. Hepatocytes from sham operated rat livers or from regenerating livers were isolated using a two-step collagenase perfusion technique as described previously [Hashimoto et al., 1993]. Since we have compared hepatocytes obtained from regenerating livers, sham operated rats are referred to as controls in the text. Hepatocyte viability was tested by trypan blue exclusion ( $>90 \%$ ). The hepatocytes were plated at a cell density of $10^{5}$ per $16-\mathrm{mm}$ tissue culture dish coated with $250 \mu \mathrm{l}(1: 3 \mathrm{v} / \mathrm{v})$ of Matrigel ${ }^{\text {IM }}$ (laminin, heparin sulfate, type IV collagen) and were examined under the microscope daily. Hepatocytes were also obtained from sham operated rats, and are referred to as control rats.

\section{Immunoblot}

In order to ascertain that there was no cell toxicity due to addition of reagents, we have monitored the secretion of albumin in the culture media and the data are reported in our previous publications [Hashimoto et al., 1993;
Raper et al., 1991b]. Secreted albumin was demonstrated by immunoblots using antirat albumin antibodies as described previously. Morphology of the cells did not change for the duration of the experiment. ${ }^{35}$ S-Cysteine incorporation into cells was previously analyzed by immunoprecipitation of albumin in media. This lead us to conclude that the cultures contained viable hepatocytes for use in our studies.

\section{Estimation of DNA Synthesis}

DNA synthesis was estimated by the rate of ${ }^{3} \mathrm{H}$-thymidine incorporation into DNA and by autoradiography measurement of the number of labeled nuclei [Hashimoto et al., 1993]. Briefly, hepatocytes were plated for $24 \mathrm{~h}$ in minimum essential medium (serum free). After $24 \mathrm{~h}$ of attachment, fresh media containing the reagents was added. ${ }^{3} \mathrm{H}$-thymidine was added $6 \mathrm{~h}$ after reagents were added. Cells were harvested $18 \mathrm{~h}$ after addition of ${ }^{3} \mathrm{H}$-thymidine. Half of the harvested cells were processed for ${ }^{3} \mathrm{H}$-thymidine incorporation and the other half of the cells were used to determine DNA content. ${ }^{3} \mathrm{H}$-Thymidine incorporation was monitored by filtering cells on to glass microfiber Whatman filters (Whatman International, Maidstone, U.K.), rinsed with $1.0 \mathrm{ml}$ of $15 \%$ ice-cold trichloroacetic acid two times and then $1.0 \mathrm{ml}$ of $70 \%$ ethanol once. Filters were dried and then placed in $10 \mathrm{ml}$ of scintillation cocktail (Ecolite, ICN Biochemicals Inc., Irvine, CA) and were counted in a scintillation counter (Beckman LS 6000 LL, Beckman Instruments, Fullerton, CA). A modified diphenylamine reaction for desoxypentose was performed to measure DNA content. ${ }^{3} \mathrm{H}$ thymidine incorporation was expressed as $\mathrm{cpm} /$ $\mu \mathrm{gDNA}$. Nuclei labeled with ${ }^{3} \mathrm{H}$-thymidine was also measured.

The labeling index, i.e., the percentage of nuclei labeled with ${ }^{3} \mathrm{H}$-thymidine, was measured as follows. After $18 \mathrm{~h}$ exposure to ${ }^{3} \mathrm{H}$-thymidine ( 2 $\mu \mathrm{Ci} /$ dish), hepatocytes were washed twice with ice-cold phosphate-buffered saline and fixed in $4 \%$ paraformaldehyde for $10 \mathrm{~min}$, coated with Kodak NTB-3 emulsion, and exposed for 10 days before development. The percentage of morphologically defined hepatocytes with labeled nuclei was determined by phase contrast microscopy.

\section{Binding Assay}

Labeling of the somatostatin ligand (tyr ${ }^{11}$-SS14) and binding studies were performed as described previously [Raper et al., 1992]. Briefly, 
binding of ${ }^{125} \mathrm{I}-\mathrm{tyr}^{11}$-SS-14 $(50 \mathrm{pM})$ to hepatocytes $\left(2 \times 10^{5} / \mathrm{ml}\right)$ was carried out in $0.5 \mathrm{ml}$ of binding buffer $\left(1 \mathrm{mM} \mathrm{NaHCO}_{3}, 0.5 \mathrm{mM} \mathrm{CaCl}_{2}, 2\right.$ $\mu \mathrm{M}$ leupeptin, $2 \mu \mathrm{M}$ pepstatin, $1 \mathrm{mM}$ PMSF, and $0.1 \mathrm{mg} / \mathrm{ml}$ bacitracin) at $\mathrm{pH} 7.5$, for $30 \mathrm{~min}$ at $25^{\circ} \mathrm{C}$. Hepatocytes ${ }^{125} \mathrm{I}$-tyr ${ }^{11}$-SS-14 was separated by centrifugation and washed with $1.0 \mathrm{ml}$ of icecold binding buffer. The pellet's radioactivity was monitored by a gamma-counter. ${ }^{125} \mathrm{I}_{\text {-tyr }}{ }^{11}$ SS-14 binding to hepatocytes in the presence of $10 \mu \mathrm{M}$ SS-14 was considered to be nonspecific binding. Specific binding was obtained by subtracting nonspecific counts from counts obtained in absence of SS-14, followed by division with total counts minus nonspecific counts. Nonspecific binding was less than $5 \%$.

\section{Affinity Cross-Linking}

One million hepatocytes obtained from control rats and at various intervals after partial hepatectomy were incubated in $0.5 \mathrm{ml}$ of binding buffer in the presence ${ }^{125}{ }^{2}$-tyr ${ }^{11}$-SS-14 (200 $\mathrm{pmol} / \mathrm{L}$ ) for $30 \mathrm{~min}$ at $25^{\circ} \mathrm{C}$. The mixture was centrifuged at $10,000 \mathrm{~g}$ for $15 \mathrm{~min}$ at $4^{\circ} \mathrm{C}$. The pellet was washed with $1.0 \mathrm{ml}$ of icecold binding buffer and then centrifuged at $10,000 \mathrm{~g}$ for 10 min at $4^{\circ} \mathrm{C}$. The homobifunctional cross-linking agent DSS was prepared in DMSO (1:100) at final concentration of $1 \mathrm{mM}$. The reaction between pellet and DSS was allowed to proceed for $20 \mathrm{~min}$ at $4^{\circ} \mathrm{C}$ and then quenched with $1 \mathrm{ml}$ of 1 $\mathrm{M}$ ammonium acetate for $5 \mathrm{~min}$ at $25^{\circ} \mathrm{C}$. Pellets were washed with ice-cold binding buffer and the subjected to SDS-PAGE.

\section{SDS-PAGE}

SDS-PAGE analysis is described in detail in our previous publication [Raper et al., 1992]. Briefly, affinity cross-linked membranes were solubilized in the sample buffer $(0.0625 \mathrm{M}$ Tris$\mathrm{HCl}, \mathrm{pH} \mathrm{6.8),} \mathrm{5 \%} \mathrm{\beta -mercaptoethanol} \mathrm{(v:v),} 2.3 \%$ SDS (wt:v), $10 \%$ glycerol (v:v), and $5 \%$ bromophenol blue (wt:v) by heating at $100^{\circ} \mathrm{C}$ for $3 \mathrm{~min}$. Samples were then subjected to electrophoresis in $7.5 \%$ acrylamide and $1 \%$ SDS. Gels were fixed, silver stained for the identification of the molecular markers, and dried. Autoradiography was performed on dried gels by exposing them to Kodak X-Omat AR film with an enhancing screen at $-70^{\circ} \mathrm{C}$. Cross-linking efficiency was $1-2 \%$ as determined by counting the radioactivity of the cut dried laneblocks $(0.5 \mathrm{~cm})$.

\section{Statistical Analysis}

All values shown represent the mean $\pm S E M$. Wilcoxon signed rank or Student's $t$-test, as appropriate, to compare the various groups. Somatostatin effects on insulin stimulated ${ }^{3} \mathrm{H}$. thymidine incorporation, cAMP synthesis, and nuclear labeling index were also performed by analysis of variance (ANOVA). The level of sig. nificance was established at $P<0.05$.

\section{RESULTS}

The cultures of isolated hepatocytes from regenerating liver and intact liver had the known characteristics. Hepatocytes, when cultured on Matrigel ${ }^{(\mathrm{M}}$, attached rapidly and exhibited minimal spreading, which was different from the flattened appearance of hepatocytes cultured on plastic. The cells were polygonal and nucleated. The control experiments showed no fibroblastic growth during experimental time.

Preliminary experiments showed that $20 \mathrm{nM}$ insulin significantly stimulated tritiated thymidine incorporation into control rat hepatocytes DNA using various concentrations of insulin. Further, $10 \mathrm{nM}$ of SS-14 significantly inhibited insulin stimulated tritiated thymidine incorporation into control rat hepatocytes DNA [Raper et al., 1991b]. Hence, concentrations of $20 \mathrm{nM}$ of insulin and $10 \mathrm{nM}$ of somatostatin were used in the experiments in the present study.

As shown in Figure 1, SS-14 significantly inhibited insulin-stimulated tritiated thymidine incorporation in culture obtained from control rat livers. In contrast, there was no significant inhibition of insulin-stimulated tritiated thymidine incorporation in hepatocytes obtained from the rats liver $2,6,18$, and $24 \mathrm{~h}$ after partial hepatectomy. The percentage of nuclei labeled with tritiated thymidine, or nuclear labeling index, is shown in Table I. SS-14 significantly inhibited the insulin stimulated labeling index in control operated rat hepatocytes but did not inhibit it in hepatocytes obtained at $18 \mathrm{~h}$ after partial hepatectomy.

Since glucagon is a known mitogen for hepatocyte proliferation, we determined the effects of SS-14 on glucagon stimulated tritiated thymidine incorporation in hepatocytes in culture obtained from control and $18 \mathrm{~h}$ regenerating rat livers. As shown in Figure 2, SS-14 significantly inhibited tritiated thymidine incorporation in hepatocytes obtained from control rats, but there 


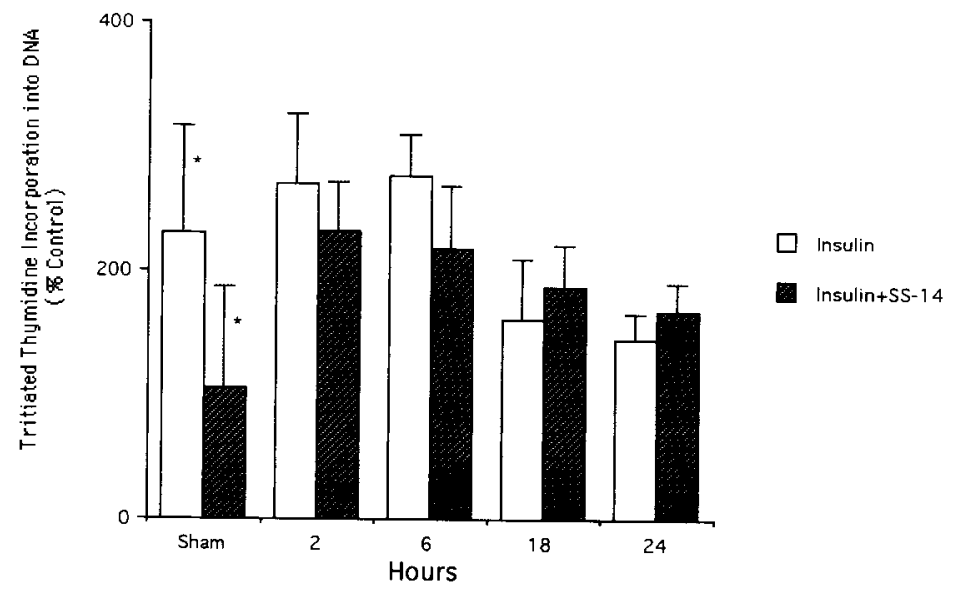

Fig. 1. Effect of SS-14 on insulin-stimulated tritiated thymidine incorporation into hepatocyte DNA in control and hepatectomized rats. On ordinate, tritiated thymidine incorporation in

TABLE I. Effect of SS-14 in Insulin Stimulated Nuclear Labeling Index in Hepatocytes Obtained at $18 \mathrm{~h}$ After Partial Hepatectomy ${ }^{\dagger}$

\begin{tabular}{lcc}
\hline & \multicolumn{2}{c}{$\begin{array}{c}\text { \% Nuclear labeling } \\
\text { (mean } \pm \text { SEM) }\end{array}$} \\
\cline { 2 - 3 } & \multicolumn{1}{c}{ Control } & HTX \\
\hline MEM & $24.6 \pm 5.3^{*}$ & $18.9 \pm 2.7^{* * *}$ \\
Insulin 20 nM & $38.5 \pm 7.7^{* * *}$ & $42.6 \pm 7.1^{* * *}$ \\
Insulin 20 nM + & & \\
SS-14 10 nM & $23.1 \pm 4.3^{* *}$ & $34.7 \pm 7.2$ \\
\hline
\end{tabular}

'Statistical analysis was performed by ANOVA.

$*, * *, * * * P<0.05$, when compared with each other.

was no inhibition of in hepatocytes obtained from the $18 \mathrm{~h}$ regenerating livers.

We have reported that insulin stimulated cAMP accumulation in hepatocytes obtained from sham operated rats was inhibited by SS-14 [Raper et al., 1991b]. However, insulin stimulated cAMP accumulation in hepatocytes obtained $18 \mathrm{~h}$ after partially hepatectomized rats was significantly inhibited by SS-14 (Table II). Further, intracellular cAMP levels were significantly higher in hepatocytes obtained from regenerating livers than control livers.

To determine whether SS-14 acts via its own receptor on hepatocytes, we examined the binding of ${ }^{125}{ }^{1-t y r}{ }^{11}$-SS-14 to hepatocytes at various times. As shown Figure 3, the binding of ${ }^{125} \mathrm{I}$ tyr ${ }^{11}$-SS-14 to hepatocytes in control rats was significantly higher than hepatocytes obtained after partial hepatectomy. There was a time dependent increase in binding to hepatocytes that were obtained from hepatectomized rats. control and at 2, 6, 18, $24 \mathrm{~h}$ after partial hepatectomy is expressed as a percentage of its own matched control. The vertical bar indicates mean \pm SEM. ${ }^{*} P<0.05(\mathrm{~N} \geq 6)$.

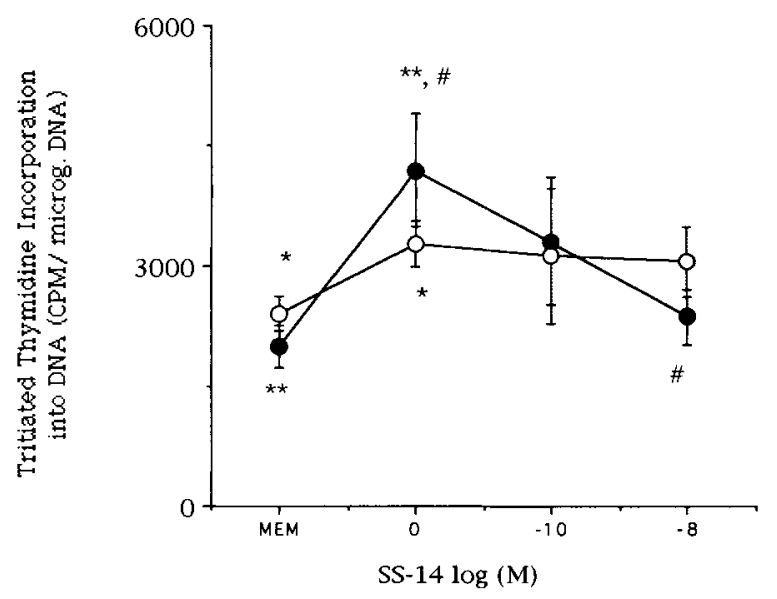

Fig. 2. Effect of SS-14 on glucagon-stimulated tritiated thymidine incorporation into hepatocyte DNA in control (closed circle) and $18 \mathrm{~h}$ regenerating liver (open circle). Tritiated thymidine incorporation in control and at $18 \mathrm{~h}$ after partial hepatectomy is indicated on ordinate. The vertical bar indicates mean \pm SEM. ${ }^{*},{ }^{* *}, \#=P<0.05$. MEM $=$ minimum essential media $(\mathrm{N} \geq 3)$.

${ }^{125} \mathrm{I}$-tyr ${ }^{11}$-SS- 14 binding to hepatocytes was undetectable at $2 \mathrm{~h}$ after hepatectomy, and was significantly less at 6,18 , and $24 \mathrm{~h}$ after hepatectomy than that of control rats.

In order to determine whether the decreased binding of ${ }^{125}$ I-tyr ${ }^{11}$-SS-14 to hepatocytes obtained from regenerating livers in comparison to control livers is due to change in the affinity of the receptors to bind ${ }^{125}$ I-tyr ${ }^{11}$-SS-14 or in its number, we studied the competition binding curve profiles using synthetic SS-14. As shown in Figure 4, increasing concentrations of synthetic SS-14 to the hepatocytes obtained $18 \mathrm{~h}$ 
TABLE II. Effect of SS-14 in Insulin Stimulated Intercellular cAMP in Hepatocytes Obtained at 18 h After Partial Hepatectomy

\begin{tabular}{lcc}
\hline & \multicolumn{2}{c}{$\begin{array}{c}\text { cAMP (pmol) } \\
\text { (mean } \pm \text { SEM) }\end{array}$} \\
\cline { 2 - 3 } & \multicolumn{1}{c}{ Control } & \multicolumn{1}{c}{ HTX } \\
\hline MEM & $0.180 \pm 02^{*, \#}$ & $0.42 \pm 0.11^{*, * *}$ \\
Insulin 20 nM & $0.45 \pm 0.08^{*,(}$ & $1.62 \pm 0.37^{* *, * * *}$ \\
Insulin 20 nM + & & \\
$\quad$ SS-14 10 nM & $0.23 \pm 0.32^{\Theta}$ & $0.93 \pm 0.46^{* * * *}$ \\
\hline
\end{tabular}

$*,(i, \#, * *, * * *=P<0.05$, when compared with each other.

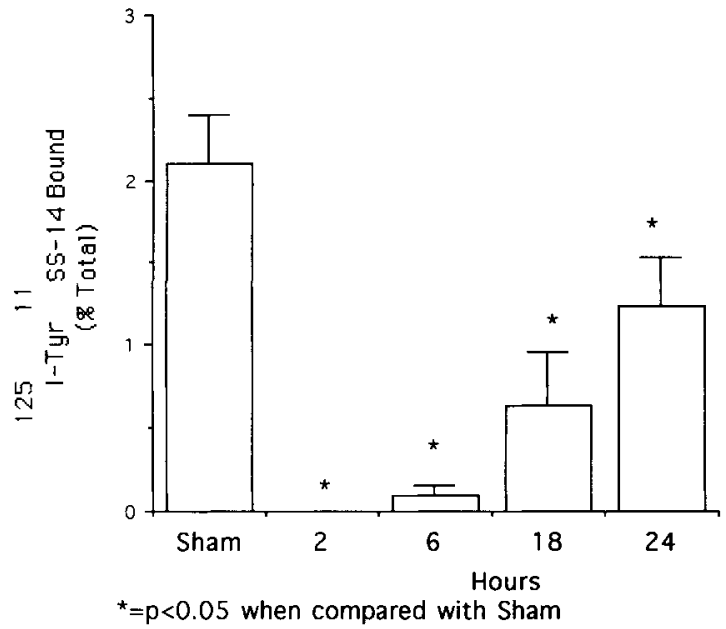

Fig. 3. Binding of ${ }^{125}-$ tyr $^{11}-\mathrm{SS}-14$ to hepatocytes during liver regeneration. Specific binding to hepatocytes after 2, 6, 18, or $24 \mathrm{~h}$ after partial hepatectomy is indicated on ordinate, and is expressed as a percent of the control rats. The vertical bar indicates mean \pm SEM. ${ }^{*} P<0.05$ when compared with control group $(\mathrm{N} \geq 3$ ). Specific binding was calculated by subtracting total binding at each point minus the nonspecific binding (see Materials and Methods).

after partial hepatectomy and control livers resulted in a characteristic competition binding profile. Further ${ }^{125} \mathrm{I}_{\text {-tyr }}{ }^{11}$-SS-14 binding to hepatocytes obtained from control livers and $18 \mathrm{~h}$ regenerating livers showed two binding sites in each case. There was no statistically significant change in binding affinities; however, there was a significant decrease in number of high affinity binding sites $(1,413 \pm 153$ vs. $246 \pm 73, P<$ $0.05)$ during liver regeneration as determined by Scatchard analysis (Fig. 5, Table III).

To ascertain that there was significantly less binding of ${ }^{125}$ I-tyr $^{11}$-SS-14 to hepatocytes obtained from regenerating liver than that from control livers, we covalently cross-linked the bound complex using homobifunctional crosslinking reagent, DSS. Autoradiograms from SDS-

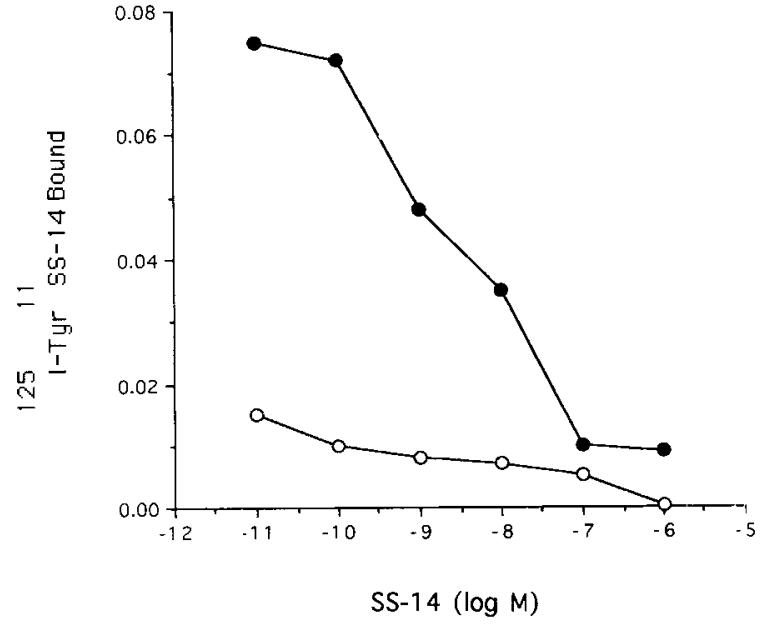

Fig. 4. Displacement of ${ }^{125} \mathrm{I}-\mathrm{tyr}^{11}$-SS-14 binding to hepatocytes obtained from control livers (closed circle) and $18 \mathrm{~h}$ regenerating livers (open circle). Hepatocytes and $125 \mathrm{I}$-tyr SS-14 $(50 \mathrm{pmol} / \mathrm{L})$ were incubated with the increasing concentration of synthetic SS-14. The data are representative of four or more experiments.

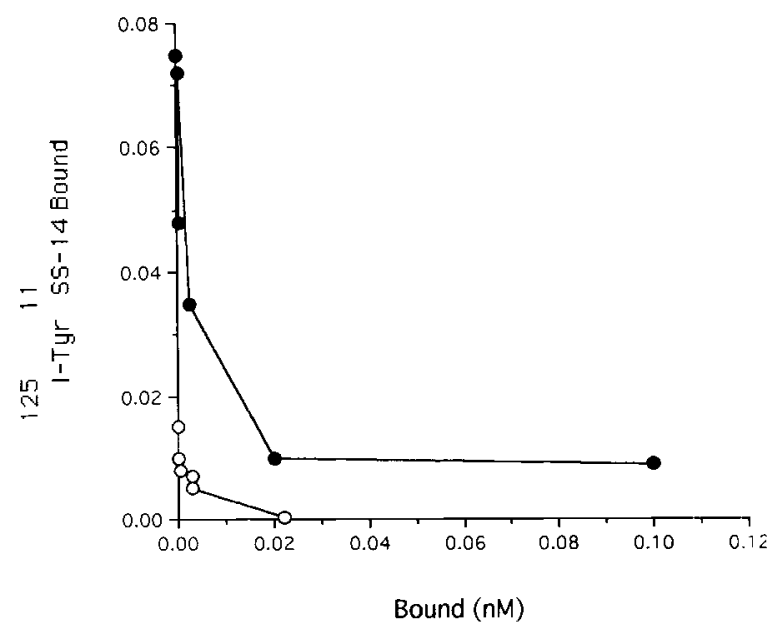

Fig. 5. Scatchard plot of ${ }^{125}$-tyr ${ }^{11}$-SS-14 binding to hepatocytes obtained from rats $18 \mathrm{~h}$ after control livers (closed circie) or $18 \mathrm{~h}$ regenerating livers (open circle). Hepatocytes were incubated with ${ }^{125} \mid$-tyr ${ }^{11}$-SS-14 and increasing concentrations of synthetic SS-14. Each point is a mean of duplicate determinations from an experiment and is a representative of four experiments.

PAGE gels of the cross-linked ${ }^{125}$ I-tyr ${ }^{11}$-SS-14 complexes showed a band of radioactivity of molecular weight $70,000 \mathrm{D}$ in hepatocytes obtained from control, 6 , and $24 \mathrm{~h}$ regenerating livers. In order to compare the intensity of the band, care was taken to incubate equal amounts of hepatocytes protein with same amount of radioactivity. A fainter band was obtained in hepatocytes obtained at $6 \mathrm{~h}$ than those obtained from sham operated livers (Fig. 6). There were 
TABLE III. Binding Affinities of ${ }^{125}$ I-tyr ${ }^{11}$-SS-14 for its Binding Sites on Rat Hepatocytes Obtained After Sham Operation or $18 \mathrm{~h}$ After Hepatectomy ${ }^{\ddagger}$

\begin{tabular}{lccccc}
\hline & \multicolumn{2}{c}{$\begin{array}{c}\text { Affinity constant }(\mathrm{Kd}) \\
\mathrm{nM} \text { (mean } \pm \mathrm{SEM})\end{array}$} & & \multicolumn{2}{c}{$\begin{array}{c}\text { No. of binding } \\
\text { sites (mean } \pm \text { SEM) }\end{array}$} \\
\cline { 2 - 3 } \cline { 5 - 6 } & High & Low & & High & Low \\
\hline Sham & $6.55 \pm 0.61$ & $510 \pm 203$ & & $1,413 \pm 153^{*}$ & $8,309 \pm 2,392$ \\
Regenerating liver & $5.05 \pm 1.47$ & $465 \pm 98$ & & $246 \pm 73^{*}$ & $6,458 \pm 2,492$ \\
\hline
\end{tabular}

${ }^{\dagger}$ Values were obtained by Scatchard analysis and represent the mean \pm SEM from 4 separate experiments.

$* P<0.05$.
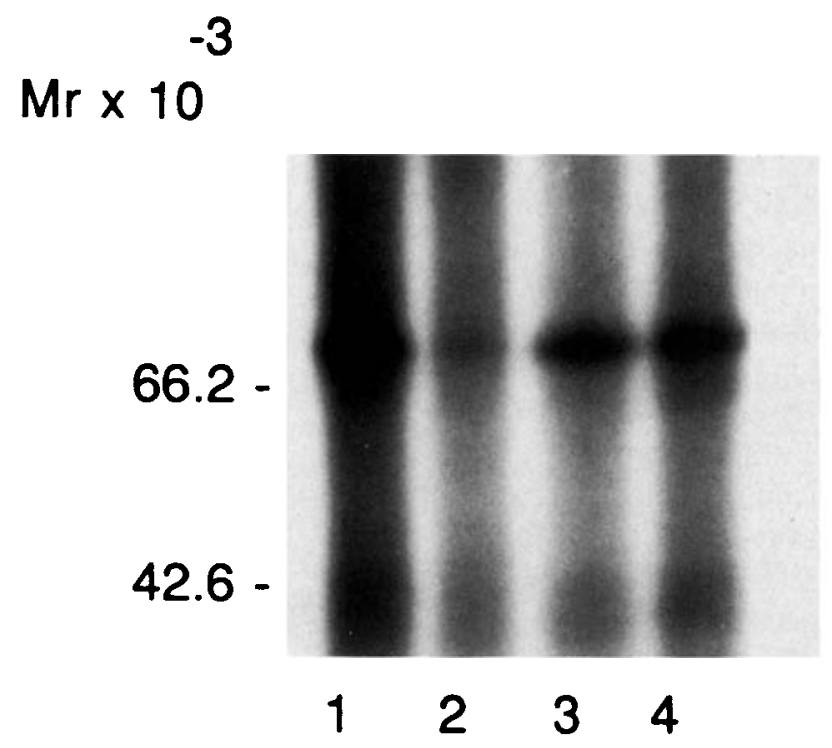

Fig. 6. Affinity labeling of ${ }^{125}$ l-tyr ${ }^{11}-\mathrm{SS}-14$ binding protein on hepatocytes obtained from sham operated (sham) and regenerating livers. Lane 1, sham; lane 2,6 h; lane 3,18 h, and lane 4, $24 \mathrm{~h}$ after partial hepatectomy. Hepatocytes were incubated with ${ }^{125} \mathrm{I}-\mathrm{tyr}^{11}$-SS-14 (200 pmol/L) separately and then washed

no major differences observed in the intensity of the band obtained from control and $24 \mathrm{~h}$ regenerating livers.

\section{DISCUSSION}

The present studies demonstrate that the antiproliferative effect of SS-14 on insulin stimulated isolated rat hepatocytes proliferation was observed in hepatocytes obtained from control rats but was not observed in the hepatocytes obtained in regenerating livers between 2 and $24 \mathrm{~h}$ after partial hepatectomy. Similarly, glucagon-stimulated tritiated thymidine incorporation showed inhibition by SS-14 in hepatocytes obtained from control rats but there was no inhibition by SS-14 in hepatocytes obtained $18 \mathrm{~h}$ after partial hepatectomy. Our findings also indicate that the inhibitory effect of SS-14 is not caused by cytotoxicity, since albumin secretion

with ice-cold binding buffer. The radiolabeled complex was cross linked with $100 \mu \mathrm{mol} / \mathrm{M}$ DSS for $20 \mathrm{~min}$ at $4^{\circ} \mathrm{C}$ and then quenched (see Materials and Methods). Cross-linked complex was then subjected to SDS-PAGE (7.5\%). An autoradiography is representative of two experiments.

in presence of SS-14 continued [Hashimoto et al., 1993] and the cells appear healthy and viable. The preferential inhibition of the antiproliferative effect of SS-14 on hepatocytes obtained after partial hepatectomy supports the hypothesis that HTX removes the proliferative suppressive effects of SS-14 by a reduction in SS-14 receptor number in regenerating liver.

The concentration of SS-14 needed to inhibit the DNA synthesis of insulin and glucagon in our control preparations was $10 \mathrm{nM}$, which is higher than the circulatory concentration [Berelowitz et al., 1978]. Such differences may be explained by the short half-life of SS-14 and its rapid degradation in culture [Chou et al., 1987; Sacks et al., 1977, 1984]. Further, SS-14 is found in low concentrations in liver [Patel et al., 1981] and high concentrations in pancreas and gastric mucosa, where it acts in a paracrine fashion 
[Orci and Unger, 1975; Guillemin and Gerich, 1976]. It is possible that transitory increases in local cellular concentration of SS-14 may induce its paracrine action in control state. The absence of inhibitory action of SS-14 during liver regeneration may be due to number of causes. Limitation in availibility of number receptor sites of SS-14 may result in lack of inhibitory action by SS-14.

Our data demonstrate that ${ }^{125} \mathrm{I}$-tyr ${ }^{11}$-SS-14 specifically binds to hepatocytes (Fig. 4), and when bound material is cross-linked with homobifunctional cross-linking reagent, solubilized, electrophoresed on polyacrylamide, and autoradiographed, a single labeled protein band of the molecular weight equal to 70,000 was observed (Fig. 6). This observation is agreement with our previous observation of a somatostatin specific binding protein of the molecular weight equals 70,000 on rat liver plasma membranes [Raper et al., 1992]. Further, we have identified high and low affinity binding sites in hepatocytes (Fig. 5, Table III). This observation is supported by Yamada et al. [1992]. However, we could identify only one site in liver plasma membranes [Raper et al., 1992]. Variation could be explained by the loss of binding sites in the liver plasma membranes by the harsher treatment during isolation of the plasma membranes. Besides, the data are similar to those in parietal cells and lymphocytes [Sreedharn et al., 1989; Parks et al., 1985]. The high affinity binding sites were significantly lower in the regenerating liver when compared to control rats. However, the affinity constant remain unchanged in hepatocytes obtained from control and regenerating livers. The decrease in the number of binding sites during liver regeneration can explain the lack of SS-14 action in inhibiting tritiated thymidine incorporation in regenerating liver (Fig. 1, Table I). The observation of a faint band at a molecular weight equal to 70,000 at 6 $\mathrm{h}$ after hepatectomy (Fig. 6) further confirms our observation of less binding of SS-14 to its binding sites just after hepatectomy (Fig. 3). The data support a physiological role for the recently identified hepatic SS-14 receptor [Raper et al., 1992; Ziegeler et al., 1988] and its mRNA in the liver [Yamada et al., 1992]. Second messenger systems participate in the regulation of cellular proliferation [Dumont et al., 1989]. The adenylate cyclase system is a well known second messenger system that has been postulated to play a major role in the cell proliferation [Ha- segwa et al., 1980; Kokudo et al., 1991; Raper et al., 1991b]. In addition, the SS-14 receptor is shown to be coupled to the adenylyl cyclase system in several types of cells [Reisine and Gould, 1989]. Our studies show that there is an increase in intracellular cAMP synthesis during liver regeneration (Table II). This data support the observation of Whitfield et al. [1980] of increased cAMP levels in regenerating liver tissues. Further, insulin stimulates intracellular cAMP accumulation in the isolated hepatocytes and is inhibited by SS-14 in control rats (Table: II). These data are in agreement with the observation of Gettys et al. [1988] of increased accumulation (between 2 and $5 \mathrm{~min}$ ) of preloaded hydrolyzable analogue of cAMP in the hepato. cytes. In regenerating liver, SS-14 inhibited in-. sulin stimulated cAMP accumulation (Table II) The data indicate that SS-14 binding sites are coupled to the adenylate cyclase system in regenerating livers as well.

Liver regeneration provides an in vivo and in vitro model to understand proliferative processes. Decreases in somatostatin binding sites in regenerating livers open up new avenues to study the mechanism of decreases in number and negative control. However, since somat ostatin inhibits DNA synthesis in control hepatocytes but has no effect on hepatocytes obtained from 2 to $24 \mathrm{~h}$ regenerating livers [Kokudo et al., 1992] (Figs. 1, 2, Table I) and the binding sites are regulated by guanine nucleotide protein [Raper et al., 1992], it can be concluded that SS-14 binding to its receptors on the liver plays a physiological role in the liver regeneration.

\section{REFERENCES}

Berelowitz M, Kronheim S, Pimstone B, Shapiro B (1978): Somatostatin-like immunoreactivity in rat blood-characterization, regional differences and response to oral and intravenous glucose. J Clin Invest 62:1410-1414.

Brazeau P, Vale W, Burgus R, Ling N, Butcher M, Riever J, Guillemin R (1973): Hypothalamic polypeptide that inhib its the secretion of immunoreactive pituitary growth hor. mone. Science 179:77-79.

Chou CK, Ho LT, Ting LP, Hu C, Su TS, Chang WC, Suen CS, Huang MY, Chang C (1987): Selective suppression of insulin-induced proliferation of cultured human hepatoma cells by somatostatin. J Clin Invest 79:175-178.

Conlon JM, Whittaker J, Hammond V, Alberti KGMM (1981): Metabolism of somatostatin and its analogues by the liver, Biochim Biophys Acta 677:234-242.

Dumont JE, Jauniaux JC, Roger PP (1989): The cyclic AMP-mediated stimulation of cell proliferation. Trends Biochem Sci 14:67-71. 
Gettys TW, Blackmore PF, Corbin JD (1988): An assessment of phosphodiesterase activity in situ after treatment of hepatocytes with hormones. Am J Physiol 254:E449E453.

Guillemin R, Gerich JE (1976): Somatostatin-physiological and clinical significance. Annu Rev Med 27:379-388.

Harris AG (1990): Future medical prospects of sandostatin. Metabolism 39(Suppl 2):180-185.

Hasegwa K, Namai K, Koga M (1980): Induction of DNA synthesis in adult rat hepatocytes cultured in a serumfree medium. Biochem Biophys Res Commun 95:243-248.

Hashimoto M, Kothary PC, Raper SE (1993): Effects of TGF $\alpha$ and somatostatin on processing of liver regeneration in the rats. Regul Pept 44:49.

Kokudo N, Kothary PC, Eckhauser FE, Raper SE (1991): Inhibitory effects of somatostatin on hepatocyte proliferation are mediated by cAMP. J Surg Res 51:113-118.

Kokudo N, Kothary PC, Eckhauser F, Nakamura T, Raper SE (1992): Inhibition of DNA synthesis by somatostatin in rat hepatocytes. Stimulated by hepatocyte growth factor or epidermal growth factor. Am J Surg 163:169-173.

Larsson LI, Goltermann N, DeMagostris L, Rehfeld JF, Schwartz TW (1979): Somatostatin cell processes as pathways for paracrine secretion. Science 205:1393-1397.

Morriset J (1984): Somatostatin: A potential antigrowth factor for the exocrine pancreas. Regul Pept 10:11-22.

Orci L, Unger RH (1975): Functional subdivision of islets of langerhans and possible role of D-cells. Lancet ii:12431244.

Parks J, Chiba T, Yokotani K, Delvalle J, Yamada T (1985): Somatostatin receptors on canine fundic D-cells: Evidence for autocrine regulation of gastric somatostatin. Am $J$ Physol 257:G235-G241.

Patel YC, Wheatley T, Ning C (1981): Multiple forms of immunoreactive somatostatin: Comparison of distribution in neural and non-neural tissues and portal plasma in the rat. Endocrinology 109:1943-1949.

Raper SE, Kothary PC, Kokudo N, DelValle J (1991a): The liver plays an important role in the regulation of somatostatin-14 metabolism in the rat. Am J Surg 161:184-189.

Raper SE, Kothary PC, Kokudo N (1991b): Somatostatin-14 blocks the hepatotrophic effects of insulin in the rat. $J$ Surg Res 50:386-390.
Raper SE, Kothary PC, DelValle J (1992): Identification and partial characterization of a somatostatin-14 binding protein on rat liver plasma membrane. Hepatology 16:433439.

Reisine T, Gould S (1989): Pertussis toxin blocks somatostatin inhibition of calcium mobilization and reduces the affinity of somatostatin receptors for agonists. J Pharmacol Exp Ther 235:551-557.

Ruggere MD, Patel YC (1985): Hepatic metabolism of somatostatin-14 and somatostatin-28: Immunohistochemical characterization of the metabolic fragments and comparison of cleavage sites. Endocrinology 117:88-96.

Sacks HS, Terry LC, Wright RK, Stenz FB (1984): Somatostatin metabolism: Difference in clearance of $\mathrm{N}$-terminal and central portion of molecule during perfusion of rat liver. Am J Physiol 146:G226-234.

Sacks HS, Waligora K, Matthews J, Pimstone BL (1977): Inhibition by somatostatin of glucagon-induced glucose release from the isolated perfused rat liver. Endocrinology 101:1751-1759.

Sreedharan SP, Kodama KT, Peterson KE, Goetzl EJ (1989): Distinct subsets of somatostatin receptors on cultured human lymphocytes. J Biol Chem 264:949-952.

Weinstein I, Wasfi I, Heimberg M (1981): Lack of effect of somatostatin on the glucagon-induced alteration of hepatic metabolism of $\left(1-{ }^{14} \mathrm{C}\right)$ oleate. Biochim Biophys Acta 664: 124-132

Whitfield JF, Boynton AL, MacManus JP, Rixon RH, Sikorska M, Tsang B, Walker PR, Swierenga SHH (1980): The role of calcium and cyclic AMP in cell proliferation. Ann $\mathrm{N}$ Y Acad Sci 339:216-240.

Yamada Y, Post SR, Wang K, Tager HS, Bell GI, Seino S (1992): Cloning and functional characterization of a family of human and mouse somatostatin receptors expresses in brain, gastrointestinal tract and kidney. Proc Natl Acad Sci U S A 89:251-255.

Ziegler K, Frimmer M, Kessler H, Haupt A (1988): Azidobenzamido-008, a new photosensitive substrate for the "multispecific bile acid transporter" of hepatocytes: Evidenced for a common transport system for bile acids and cyclosomatostatins in basolateral membranes. Biochim Biophys Acta 945:263-272. 